\title{
Major Constraints and Health Management of Village Poultry Production in Ethiopia: Review School of Veterinary Medicine, Jimma University, Jimma, Ethiopia
}

\author{
Ahmed Mohammed \\ P.O.Box 307, Jimma, Ethiopia \\ *Corresponding Author: Ahmed Mohammed, P.O.Box 307, Jimma, Ethiopia

\begin{abstract}
Village chicken production in Ethiopia is generally characterized by little inputs for housing, feeding (scavenging is the only source of diet) and health care with high level of mortality.In most area of the country chicken owners do not properly examine their chicken and they do not vaccinate their chicken. Critical constraints for village poultry production in Ethiopia were identified as: diseases and predators, lack of proper health care, feed source and poor marketing information. Among diseases, Newcastle Disease (NCD) (locally called "fengil") was identified as a major and economically important health constraint that hinders the expansion of village chicken production in the country. Replacement of indigenous chickens by exotic chicken breeds is also a major threat in eroding and dilution of the indigenous genetic resources. Although local consumers generally prefer egg and meat from indigenous breed rather than that of hybrid and exotic breed, the price of chicken products varied between months of the year and was determined by a number of driving factors in the country. Some of these determinant factors affecting prices of chicken products in the country identified as: demand and supply of chicken products, market day types (holyday versus ordinary market days) and fasting seasons. Demand and supply of chicken products were highly related with religious festivals, mainly Christian festivals.
\end{abstract}

Keywords: Constraints, Ethiopia,Health management, Village Chicken.

\section{INTRODUCTION}

Ethiopia is one of the sub-Saharan African countries where most of the national economy depends on agriculture (Deressaet al., 2008). Village poultry production based mainly on a scavenging system is of enormous socio-economic significance, in terms of contribution to family nutrition and household food security throughout the developing world (Muchadeyiet al., 2007). The poultry sector in Ethiopia can be characterized into three major production systems, namely the large-scale commercial, the small scale commercial and the village or backyard poultry production system. Each can sustainably coexist and contribute to solve the socio-economic problems of different target societies (Tadelleet al., 2003a).However, the marketing system is generally informal and poorlydeveloped. The existence of a local market offering goodsale opportunities and adequate transport facilities are obvious prerequisites for family poultry development (Branckaertet al., 2000). Village chicken production in Ethiopia contributes with 90 and $92 \%$ of the national egg and poultry meat production, respectively (Tadelle, 2003).

In most developing countries rural poultry play significant roles of improving the nutritional status, income, food security and livelihood of many smallholders (Solomon et al., 2013). In Ethiopia, the agricultural sector is a corner stone of the economic and social life of the people. Employs 80-85 percent of the population and contributes 40 percent to the total GDP. Livestock production, as one component of agriculture, covers 40 percent of agricultural output playing an important role in the national economy as it contributes 13-16 percent of the total GDP (Hunduma et al., 2010).

The diverse agro ecology and agronomic practice prevailing in the country together with the huge population of livestock in general and poultry in particular, could be a promising attribute to boost up the sector and increase its contribution to the total agricultural output as well as to improve the living standards of the poor livestock keepers (Fisseha, 2009). According to CSA (2012) report population 
of chickens estimated about to be 50.38 Million and with regard to breed, 96.9 percent, 0.54 percent and 2.56 percent of the total poultry population to be indigenous, hybrid and exotic respectively.

In Ethiopia, village chickens are an integral component of the farming system of nearly all rural families, and they account for about $99 \%$ of the poultry production system (Tadelle et al., 2003) and for more than $90 \%$ of the chicken and egg output of the country (Nigussie et al., 2010). Village chicken production fits quite well with the conditions of rural households due to small feed cost, space requirement and low price of the animals (Solomon, 2003). In addition, the local chicken sector constitutes a significant contribution to human livelihood by being affordable sources of animal protein and contributes significantly to food security of poor households (Dhuguma, 2009). Despite their low productivity, this prevailing production system are known to possess desirable characters such as thermo tolerant, resistant to some disease, good egg and meat flavor, hard egg shells and high dressing percentage( Aberra, 2000). They do have also fast generation interval and high reproductive rate as they are prolific, easy to rear and their output can be generally expanded more rapidly and easily than that of other livestock (Dhuguma, 2009).

Even if, Ethiopia owned huge chicken flock; there are different factors like diseases, predators, lack of proper healthcare, feed source and poor marketing information that hinder the productivity of the chickens in most area of the country. Among the above obstacles, the poultry diseases are the main constraints incriminated for reduction of total numbers and compromised productivity (Natnael, 2015). Having an introduction of this way; theobjective of this paper are:

$>$ To overview the base lineinformation on major constraints and health management of village poultry production in Ethiopia.

\section{LITERATURE REVIEW}

\subsection{Village chicken production in Ethiopia}

Village chicken production in Ethiopia is generally characterized by little or no inputs for housing, feeding (scavenging is the only source of diet) and health care with minimal level of biosecurity, high off take rates and high level of mortality. As such, it does not involve investment beyond the cost of the foundation stock, a few handfuls of local grains and possibly simple night shades, mostly night time in the family dwellings. Mostly, indigenous chickens are kept although some hybrids and exotic breeds may be kept under this system (Dawitet al., 2008).

\subsubsection{Housing}

Housing systems in village chicken production system is rudimentary andmostly built with locally available materials. In traditional free range, there is no separate poultry house and the chickens live in family dwelling together with humans (Solomon, 2007).Mogeset al., (2010) reported that inBure district, North West Ethiopia, $77.9 \%$ of the village chicken owners provide only night shelter and only $22.1 \%$ provided separate poultry house. Another study by(Mengeshaet al., 2011) inJamma district, South Wollo reported that $41.3 \%$ and $21.2 \%$ of chicken owners share the same room and provided separate poultry house, respectively. Also another study done by(Nebiyuet al.,2013) in Amarodistrict, southern nation, nationality and people of regional state (SNNPRS) of Ethiopia shows that most (77.5\%) of chicken owners constructed a wooden perch for their chickens inside the main house for night shelter, $12.1 \%$ of the owners kept their chickens in a separate room which was enclosed in the main houseand $10.4 \%$ o f the households provided a hand woven basket for their chickens especially for newly hatched chicks and the broody hen.

\subsubsection{Feeding}

Family poultry production in Africa survives by scavenging and generally, no supplements provided except that some times, household waste fed to the birds and other circumstances the diet supplemented with grain. Similarly, in Ethiopia the chicken production is characterized by keeping under free range system with some amount of supplementary feeds like frushika, maize, sorghum, food leftover and the major feed sources are believed to be insect worms, seed and plant materials (Mekonnen, 2007).However, the availability of the supplementary feeds was reported during the dry season (November to March) following the grain harvest while the grains/grain by-products were in short supply leading to feed scarcity during the rainy reason (Alemayehuet al., 2015). 


\subsubsection{Marketing}

Poultry products in most developing countries, especially in Africa, are still expensive. The marketing system is generally informal and poorly developed (Alemayehuet al., 2015). Poultry marketing structure has not well studied in Ethiopia. The market outlets or channels available to producers are diverse at all markets, although their importance differs across markets. The major channels through which producers/farmers sell their chicken in the markets are direct sold to consumers and/or to small retails that take the chicken to large urban centers (Kenaet al.,2002). Unlike eggs and meat from commercial hybrid birds (derived from imported stock), local consumers generally prefer those from indigenous stocks (Desalew, 2012).

\section{2. Poultry health management}

\subsubsection{Bio-security measures}

The bio-security of the village poultry production system is very poor, as scavenging birds live together with people and other species of livestock. Poultry movement and droppings are very difficult to control and chickens freely roam in the household compound. There is no practice (or even viable means) of isolating sick birds from the household flocks and dead birds are left for either domestic or wild predators. Chickens and eggs are sold on open markets along with other food items. The current live bird marketing system represents a significant and potential hazard to both buyers and sellers, yet implementation of biosecurity and hygienic practices in such a system is generally difficult.The Newcastle Disease experience and the attitude of communities to handling sick birds (which are often sold) shows that marketing systems play a considerable role in the dissemination of disease over wide geographical areas in a relatively short period of time. The first recorded case of Newcastle disease was in 1970 on a poultry farm near Asmara, Eritrea, from where it spread all over Ethiopia within a short period of time. In summary, it is very difficult to apply health and bio-security measures on full day scavenging birds in small flock sizes (Solomon, 2007).

\subsubsection{Disease control measures}

Diseases were one of the major bottlenecks for village chicken productions in the studied areas. Newcastle disease was most widely distributed among the village chicken in Ethiopia. This was reported in several previous studies which employed different diagnostic methods such as virus isolation, sero-epidemiological investigations and molecular methods to confirm the presenceof the disease in Ethiopian village chicken productions(Terefe et al., 2015).

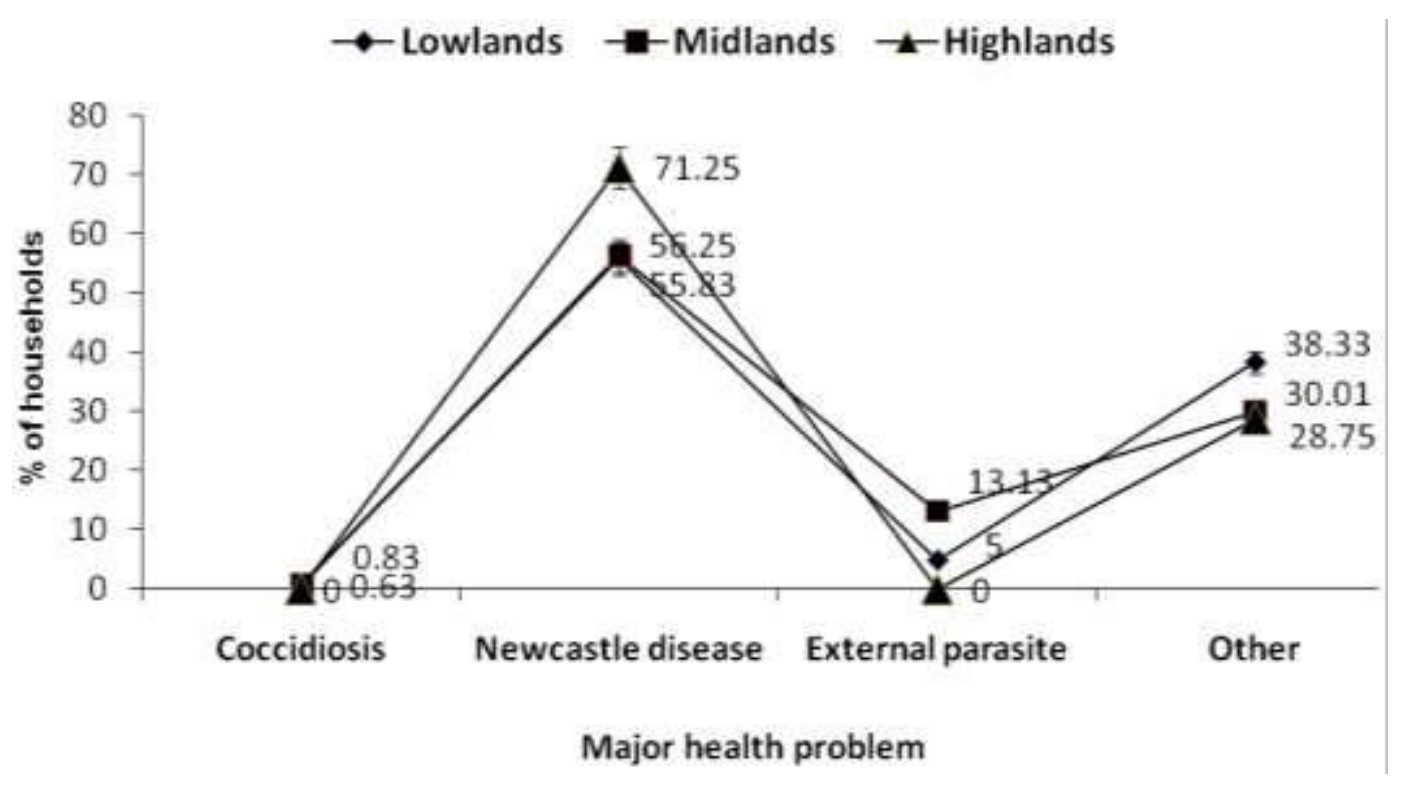

Figure1. Major poultry health problems in lowlands, midlands and highlands of Ethiopia (Zelekeet al., 2005)

In this study survey, almost 56 to $71 \%$ of the visitedfarms were affected by this disease at least once on the (Figure1). The disease occurred in all agro-climatic zones duringthe period studied, particularly affecting chicken inhighlands (71.3\%). Farmers did not know how todifferentiate the disease affecting 
their chicken in $17.9 \%$ of the cases. They knew only symptoms shown byaffected chicken. The symptoms most commonlyobserved in affected village chicken were bloody diarrhoea, nasal discharge, sneezing, torticollis and deaths withinfew days. Only $18.7 \%$ of the visited households contactedveterinarians when their chickens were sick(Mulisaet al., 2014).

According to study reported by (Halima, 2007) from northwest Ethiopia that most (72.43\%) farmers do not properly examine their chicken and provide no health management services. Also another study reported from rift valley of Oromia, that $44 \%$ of farmers in the study area usually treat sick chickens using traditional medicine whereas others (41\%) do nothing. Only $11 \%$ of the farmers consult veterinarians when their chickens get sick; this is as a result of veterinary service insufficiency. They use garlic, different kind of green leaves, lemon, local alcohol, paper powder, butter, etc as drenching, nasal application and smoking. The response to treatment vary considerably where $45 \%$ fully recovered, $33 \%$ partially recovered and $22 \%$ no response to traditional treatment (Hundumaet al.,2010).

To save their chicken during disease outbreak village poultry producer take different kind of measures like: use traditional medicine (33\%), consult veterinarian (11.4\%), call traditional healers $(10.4 \%)$, sell the survived ones (4.5\%). The wide use of traditional medicine was due to its low cost, local availability and easiness of application. Large flock sizes were obtained withthose farmers that gave traditional medicine to their chickens. This indicates that traditional medicines do work and have the potential to improve the health status of village flocks. Hence, there is a need for research to determine their chemical properties, concentrations and mode of application (Matiwoset al., 2015).

Vaccination: Vaccinesare used to prevent or reduce problems that can occur when a poultry flock is exposed to field disease organisms. Vaccination has been considered the most effective means of controlling ND and has been used successfully throughout the world since the 1940s (Dias et al., 2001). Vaccine quality is commonly blamed when a disease occurs; however, there are usually other factors responsible such as lack of a cold chain. A comprehensive investigation is often called for to identify the causes and to resolve the problem. In Ethiopia, two types of vaccines which have been used. These are: conventionally used vaccines which comprise: Hitchener B1(HB1) and LaSota live freeze dried vaccines produced in 500 and 100 dose vials, produced by NVI, Debrezeit, Ethiopia and thermo stable vaccine. The thermo stable vaccine NDV I 2 is also live freeze dried, produced in 500 dose vials. This is a non-pathogenic heat resistant vaccine, transportable without freeze and given orally with feed grain without catching birds (Wambura, 2000).

Village chicken vaccination particularly against NCD is more important than other management interventions; benefit-cost calculations done for the Tigray region of Ethiopia indicated that ND vaccination was more economically beneficial than the provision of daytime housing, supplementary feeding, cross breeding and control of broodiness (Udoet al., 2001). In village production study in different parts of Ethiopia, no vaccination practice againstpoultry diseases was reported byMogeset al.,(2010) and Mengeshaet al., (2011).

The finding of Fissehaet al., (2010) also indicated that the level of awareness about availability of vaccines for local chicken is low and the farmers do not have any experience of getting their chicken vaccinated against diseases. This is due to the fact that the farmers have no information about disease control and vaccination because of poor extension package of poultry production.

\subsection{Constraints for village poultry production}

Indigenous chickens are good scavengers as well as foragers and have high levels of disease tolerance, possess good maternal qualities and are adapted to harsh conditions and poor quality feeds as compared to the exotic breeds. In Ethiopia, however, lack of knowledge about poultry production, limitation of feed resources, prevalence of diseases (Newcastle, Coccidiosis, etc) as well as institutional and socio-economic constraints remains to be the major challenges in village based chicken productions. According to Tadelle and Ogle (2001), the primary problem cited by the village poultry farmers was high mortality of chicks.

The major causes of this problem as perceived by the community and in their order of importance were disease $(63.8 \%)$, predation $(21.8 \%)$, lack of feed $(9.5 \%)$ and lack of information $(4.9 \%)$, as per the reports of(Tadelle, 2003). Insufficient water was also one of the causes of mortality in chicks and 
older birds and a contributing factor to low productivity. The major constraints of village indigenous chicken production were partly due to poor management of the chicken (prevailing diseases and predators, lack of proper health care, poor feeding and poor marketing information). On the other hand attempt of replacing indigenous chickens by exotic chicken breeds was identified as a major threat in eroding and dilution of the indigenous chicken genetic resources (Hundumaet al., 2010).

\subsubsection{Disease}

The major causes of death for village poultry production were commonly disease (mainly New Castle Diseases locally known as ("Fengil"), followed by predation. High incidence of chicken diseases, mainly Newcastle Disease (NCD), is the major and economically important constraint for village chicken production system (Fissehaet al., 2010). Mortality of village chicken due to disease outbreak is higher during the short rainy season, mainly in April (66.8\%) and May (31.4\%). Also another reported that the NCD is one of the major infectious diseases affecting productivity and survival of village chicken in the central highlands of Ethiopia(Serkalemet al.,2005). The major routes of contamination and spread of NCD from village to village are contact between chicken during scavenging and exchange of chicken from a flock where the disease isincubating and during marketing (Tadelle and Ogle, 2001).

Another study from Benishangul-Gumuz, Western Ethiopia done by (Alemayehuet al.,2015) reported that Newcastle disease were the most prevalent and economically important disease affecting chicken in the study areas mainly during the rainy season. Shortage of supplementing feeds during rainy season makes the chickens more vulnerable to diseases. In addition to Newcastle diseases, coccidiosis and fowl typhoid are the major cause for chicken mortality (Addis and Aschalew, 2014). In Ethiopia seroprevalence surveys in village chickens have identified the presence of infectious bursal disease (Jenbreieet al., 2012), salmonellosis (Berhe et al., 2012), pasteurellosis and mycoplasma infection (Chaka et al., 2012). Parasitic diseases, including coccidiosis(Luuet al., 2013), helminthes (Molla et al., 2012)and ectoparasites (Belihuet al., 2009) have also been demonstrated to be highly prevalent in the country.

\subsubsection{Predation}

Predators were listed alongside diseases as major cause of premature death. The predation is strongly associated with the rainy season. The predators include primarily birds of prey such as vultures, which prey only on chicken and wild mammals such as cats and foxes, which prey on mature birds as well as chicks (Tadelle and Ogle, 2001). Predators such as birds of prey (locally known as "Culullee") (34\%), cats and dogs (16.3\%) and wild animals (15\%) were identified as the major causes of village poultry in rift valley of Oromia, Ethiopia (Hundumaet al.,2010). Halima (2007) also reported that predation is one of the major constraints in village chicken production in northwest Ethiopia.

Another study from Benishangul-Gumuz, Western Ethiopia done by Alemayehu et al., (2015) reported that wild cat (locally known as "shelemetmat"), eagle and foxes were the common chicken predators identified by the chicken owners in the study areas. Eagle is a serious problem in dry season while the rest are commonly attacking chicken during wet season. As reported by the chicken owners, in wet season the scavenging areas are covered by vegetation and this make a conducive environment for wild cat and foxes to attack chickens. In dry seasons, the vegetation of scavenging areas is less dense and chickens are vulnerable to eagle.

\subsubsection{Feed source and Lack of proper housing}

In Ethiopia, village chicken production systems are usually kept under free range system and the major proportion of the feed is obtained through scavenging. The major components of Scavenging Feed Resource Base (SFRB) are believed to be insects, worms, seeds and plant materials, with very small amounts of grain and table leftover supplements from the household. Improving the diet of scavenging birds is difficult because it is not known what food they are eating (Smith, 1990). The amount and availability per bird of this SFRB is significantly dependant on season, grain availability in the household, time of the grain sowing and harvest, and the biomass of the village flock.

The limited capacity of the SFRB coupled with other factors; restricts the potential productivity of local birds to about 40 to 60 eggs per hen per year (Tadelle and Ogle, 1996). However, unlike intensively kept poultry the scavenging birds are not in competition with humans for the same food 
and every egg or quantity of meat produced represents a net food increment. Any attempt at supplementation should take into consideration what the birds are actually eating (Smith, 1990) and the proportion of the total diet scavenged by birds. In village chicken production, it is difficult to estimate the economic and/or physical value of feed resource input because there are no direct methods of estimating the scavenged feed input. According to (Hundumaet al.,2010) feed shortage mostly occurs from June to August time of the year for village poultry as it is not harvesting season of cereal crops.

Although no data are available about housing at national level, the local birds are set free on free range whereby they move freely during the day and spend the night in the main house. Overnight housing, perched in trees or on roofs and overnight housing within the main house are the common patterns of housing prevailing in the country. Lack of housing is one of the constraints of the village poultry production systems. In some African countries, a large proportion of village poultry mortality accounted due to nocturnal predators because of lack of proper housing (Dwingeret al ., 2003). Some research works also indicated that the mortality of scavenging birds reduced by improved housing. For instance, in the Gambia livestock improvement program, which included improved poultry housing resulted in lower chick mortality (19\%) relative to that observed in Ethiopia (66\%) and Tanzania (33\%), where no housing improvements were made (Kitalyi, 1998).

\subsubsection{Lack of organized market and poor access to main market}

Even though chicken meat is relatively cheap and affordable source of animal protein (Alemu and Tadelle, 1997), lack of organized marketing system and the seasonal fluctuation of price are the main constraints of the poultry market in Ethiopia. Variation in price mainly attributed to high demand for chickens for Ethiopian New Year and holidays. It also partly influenced by weight, age of chickens and availability. The plumage color, sex, combs types, feather covers are also very important for influencing price. According to Gausiet al., (2004) the major constraints in rural chicken marketing were identified as low price, low marketable output and long distance to reliable markets. As a result, the smallholder farmers are not in a position to get the expected return from the sale of chickens.

Likewise, poor marketing information system, poor access to terminal market, high price fluctuation and exchange based on plumage color, age and sex are among the main constraints of chicken market in the country (Kenaet al., 2002). Despite the benefits of village poultry keeping to poor households in most parts of the country, they face significant market constraints. The distance to the nearest market is a key factor; the nearer the market, the shorter the marketing chain and the higher the price received for both live birds and eggs. It is also clear that increased involvement of intermediaries leads to reduced prices for the producer. A price reduction of $68 \%$ for birds and $25 \%$ for eggs was observed in areas with poor market access in Tigray Regional State compared to those areas with better market access. Transaction costs may be reduced through improving access to information, infrastructure and organization of the poultry producers. However, the costs of transport, credit and marketing risks should be carefully assessed (Aklilu, 2007).

A further constraint to the marketing of traditional household poultry and products is the fact that there is no packaging and weight standardization of market eggs and that traditional storage method can lead to deterioration of the quality of table eggs. According to Gausiet al.,(2004), small holder village chicken producers tend to ignore new technology even when it appears to be better than their current practices due to market limitations.

\subsubsection{Replacement of indigenous chickens by exotic chicken breeds}

The local chicken genetic resources in the Amhara region of Northwest Ethiopia were seriously endangered owing to the high rate of genetic erosion due to the extensive and random distribution of exotic breeds, by both governmental and non-governmental organizations, since they are believed to dilute the take different kind of indigenous genetic stock. This threat is also in line with the food and agriculture organization(FAO).report Replacement of indigenous chickens by exotic chicken, which states that animal genetic resources in developing countries in general, are being eroded through the rapid transformation of the agricultural system, in which the main cause of the loss of indigenous animal genetic resources is the indiscriminate introduction of exotic genetic resources, before proper characterization utilization and conservation of indigenous genetic resources(FAO, 1999). 
Replacement of indigenous chickens by exotic chicken breeds is also a major threat in eroding and dilution of the indigenous genetic resources.Establishing a constructive breeding program to address constraints related to poultry production is essential. However, the chicken genetic resources in the Amhara region of Northwest Ethiopia are becoming very sensitive due to the high rate of genetic erosion as a result of a high incidence of Newcastle disease(Hunduma et al., 2010).

Furthermore, the massive distribution of exotic chicken breeds especially the Rhode Island Red (RIR) by governmental and non- governmental organizations has resulted in the dilution of indigenous genetic stock. If this trend continues at the current rate, the gene pool of the indigenous chickens could be lost in the near future before they are properly described and studied under different management conditions (Halima et al., 2006). Marketing and the movement of poultry is the main cause of genetic mixing of chicken populations. This is why chickens from different regions or agroecologies or geographical barriers and markets tend to be more heterogeneous than chickens kept in a particular geographical location with a similar type of production. Usually chicken ecotypes are named after the name of the region (agro- ecology) or local market (e.g. ecotypes of Horro and Tepi in Ethiopia) (Tadelle, 2003)

\section{CONCLUSIONS AND RECOMMENDATION}

village chicken production is playing an important role in increasing socio-economic status of rural community and employment in rural areas. However the village chickens suffer low productivity and high mortality. Disease control and improved management village chicken production are lacking in the country. Diseases followed by predation were found to be the major constraint of village chicken production in rural area of the country. Based on the above conclusion, the following recommendations are forwarded:

* There should be appropriate intervention in disease and Predatorcontrol activities so as to reduce chicken mortality and improve productivity.

* Control of diseases should be achieved through vaccination and improvement in veterinary and advisory services.

* Efforts to increase productivity through improvements in health, feeding, housing, and daily management should be encouraged as they will result in increased economic returns.

* Training for both farmers and extension staff focusing on disease control, improved housing, and feeding, marketing systems could help to improve productivity of local chicken.

\section{REFERENCES}

Aberra, M. (2000): Comparative Studies on Performance andPhysiological RaspEthiopian Indigenous (AngeteMelata) Chickens And Their F1 Crosses To Long Term Heat Exposure. PhdDissertation,MartinLuther University. Halle-Wittenberg Germany, Pp. 127.

Addis, G. and Aschalew, T. (2014): A Phenotypic and genetic characterized indigenous chicken ecotypes in Ethiopia. Inter.J.Appl.Sci.Engr, 2(2): 22-2.

Aklilu, H.M. (2007): Village poultry in Ethiopia; socio-technical analysis and learning with farmers.PhD Thesis, Wageningen University, Wageningen, the Netherlands.

Alebachew, K. and Mekonnen, A. ( 2013): A survey on Salmonella infection among chicken flocks in Jimma town, Ethiopia. World Appl. Sci. J., 21: 1415-1420.

Alemayehu, A., Yilma, T., Shibeshi, Z. and Workneh, T. (2015): Village Chicken ProductionSystems in Selected Areas of Benishangul-Gumuz, Western Ethiopia. Asian J Poult.Sci., 9 (3): 123-132.

Alemu, Y. and Tadelle, D. (1997): The status of poultry research and development in Ethiopia,research bulletin No.4, poultry commodity research program Debrezeitagriculturalresearch center. Alemaya University of agriculture, Ethiopia.Pp. 62.

Belihu, K., Mamo, A., Lobago, F. and Ayana, D. (2009): Prevalence of ectoparasitesinbackyard local chickens in three agroecologic zones of East Shoa, Ethiopia. Rev.Med. Vet., 160: 537-541.

Berhe, N., Afera, B., Abebe, N., Tesfaya, A. and Kalayou, S. ( 2012): Seroprevalence of Salmonella pullorum infection in local and exotic commercial chiken from Mekelleareas, northern Ethiopia. RevistaElectrónicadeVeterinaria 13, 091204.

Branckaert, R., Gaviria, L., Jallade, J. andSeiders, R. (2000): Transfer of technology in poultry production for developing countries. SD dimension.FAO http://www.fao.or/sd/cddirect/cdre0054.htm 
Major Constraints and Health Management of Village Poultry Production in Ethiopia: Review School of Veterinary Medicine, Jimma University, Jimma, Ethiopia

Chaka, H., Goutard, F., Bisschop, S.P.R. and Thompson, P.N. (2012): Seroprevalence of Newcastle disease and other infectious diseases in backyard chickens at markets in Eastern Shewa zone, Ethiopia. Poult. Sci., 91: 862-869.

CSA (2012): Statistical Report on Livestock and Livestock Characteristics (Private Peasant Holdings). Statistical Bulletin 570, Volume II, April 2013. Addis Ababa.

Dawit, A., Tamrat, D., Stotaw, F., Nzietcheung, S. and Roy, D. (2008): Overview andbackground paper on Ethiopia's poultry sector. Relevance for HPAIReseasrch in Ethiopia.

Deressa,T., Hassan, R.M., Alemu, T., Yesuf, M.AndRingler, C. (2008): Analyzing the Determinants of Farmers' Choice of Adaptation Methods and Perceptions of ClimateChange in the Nile Basin ofEthiopia. IFPRI Discussion Paper 00798:1-26.

Desalew, T. (2012): Management Practices, Productive Performances And Egg Quality Traits Of Exotic Chickens Under Village Production System In East Shewa, Ethiopia. M.Sc.Thesis, Addis Ababa University, College of Veterinary Medicine and Agriculture, DebreZeit, Ethiopia.

Dhuguma, R. (2009): Understanding the role of indigenous chickens during the long walk to food security in Ethiopia. Livestock research for rural development, 21(8).

Dias, P.T., Alders, R.G., Fringe, R. and Mata, B.V. (2001): Laboratory and field trials with thermo stable live Newcastle disease vaccines in Mozambique. In: Alders RG, Spradbrow PB, ed. SADC Planning Workshop on Newcastle Disease Control in Village Chickens. Proceedings of an International Workshop, Maputo, Mozambique, 6-9 March, 2000. ACIAR Proceedings No. 103, Pp. 91-96.

Dwinger, R.H., Bell, J.G. and Permin, A. (2003): A program to improve family poultry production in Africa. B.P. 6268, Rabat-Institutes, Morocco. FAO (Food and Agriculture Organization) (2000): Statistical database of Food and Agriculture Organization of the United Nations, Rome, Italy.

FAO (Food and Agricultural Organization) (1999): Animal genetic resources information,No. 25, Rome, Italy.

FAO (Food and Agricultural Organization) (2000): Production year book. Vol.53. Rome, Italy.

Fisseha, M. (2009): Studies On Production And Marketing Systems Of Local Chicken Ecotypes In BureWoreda, North-West Amhara Regional State, Ethiopia. Msc Thesis. HawassaUniversity, Hawassa, Ethiopia.

Fisseha, M., Azage, T. and Tadelle, D. (2010): Indigenous chicken production and marketing systems in Ethiopia: Characteristics and opportunities for market-oriented development. IPMS (Improving Productivity and Market Success) of Ethiopian Farmers Project Working Paper 24.Nairobi, Kenya, ILRI.

Gausi, A., Safalaoh, J., Banda, D. and Ongola,N. (2004): Characterization of small holder poultry marketing systems in rural Malingunde: a case study of Malingunde extension planningarea; NtChell University of Malawi, Bunda College of Agriculture, Lion We, Malawi.

Halima, H. (2007): Phenotypic and genetic characterization of indigenous chicken populations in northwest Ethiopia. Ph.DThesis.University of the Free State, Bloemfontein, South Africa.

Halima, H., Nasser, W.C., Tadelle, D., De Kock, A. and Van Marle-Koster, E. (2006): Studies on the growth performance of native chicken ecotypes and RIR chicken under improved management system in northwest Ethiopia. Livestock Research Rural Development .

Hunduma, D., Regassa, C., Fufa, D., Endale, B. and Samson, L. (2010): Major Constraints and Health Management of Village Poultry Production in Rift Valley of Oromia,Ethiopia.Global veterinaria, 5(1): 06-10.

Jenbreie, S., Ayelet, G., Gelaye, E., Kebede, F., Lynch, S.E. and Negussie, H. (2012): Infectious bursal disease: seroprevalence and associated risk factors in major poultry rearing areas of Ethiopia. Trop.Anim.Health Prod., 45: 75-79.

Kena, Y., Legesse, D., and Alemu, Y. (2002): Poultry marketing: structure,spatial variations and determinants of prices in Eastern Shewa zone, Ethiopia. Ethiopian Agricultural Research Organization, Debrezeit Research Center.

Kitalyi, A.J. (1998): Village chicken production systems in rural Africa, Household food security yand gender issue. FAO Animal Production and Health Paper No. 142. Food and Agricultural Organization of the United Nations, Rome, Italy, Pp. 81.

Luu, L., Bettridge, J., Christley, R.M., Melese, K., Blake, D., Dessie, T., Wigley, P., Desta, T.T., Hanotte, O., Kaiser, P., Terfa, Z.G., Collins, M. and Lynch, S.E. (2013): Prevalence and molecular characterisation of Eimeria species in Ethiopian village chickens. BMC Vet. Res., 9: 208.

Matiwos, H., Selamawit, D.,Birhanu, A. and Asmamaw, Y. (2015): Village chicken production performances assessment under scavenging management system in Amaro district, SNNPRS of Ethiopia. Wudpecker J. Agri. Res., 4(3): $021-034$. 
Mekonnen, G. (2007): Characterization Of The Small Holder Poultry Production And Marketing System Of Dale, Wonsho And LokaabayaWeredas Of SNNPRS. M.Sc. Thesis, HawasaCollege Of Agriculture, School Of Graduate Studies, Hawassa University, Hawassa,Ethiopia.

Mekonnen, H., Mulatu,D., Kelay, B. And Berhan, T. (2010): Assessment of the nutritional status of indigenous scavenging chicken in Ada'a district, Ethiopia. Trop. Anim. Health Prod. 42:123-130

Mengesha, M., Tamir, B. and Dessie, T. (2011): Village Chicken Constraints and Traditional Management Practices in Jamma District, South Wollo, Ethiopia. Lives.Res.for Rural Dev., 23 (37).Retrieved from:http://www.lrrd.org/lrrd23/2/meng23037.htm.

Moges, F., Abera, M. and Tadelle, D. (2010): Assessment of village chicken production system and evaluation of the productive and reproductive performance of local chicken ecotype in Bure district, North West Ethiopia. African J. Agri. Res.,5(13):1739-1748.

Molla, W., Haile, H., Almaw, G. and Temesgen, W. (2012):Gastrointestinal helminthsoflocal backyard chickens in North Gondar Administrative Zone, Ethiopia. Rev. Med Vet., 163: 362-367.

Muchadeyi, F.C., Wollny,CBA.,Eding, H., Weigend, S., Makuza, S.M. andSimianer, H. (2007): Variation in village chicken production systems among agro-ecological zones of Zimbabwe. Trop. Anim. Health Prod.39:453-546.

Mulisa, D.D., Alemu, R.B., Keno, M.S., Furaso, A., Heidari, A., Chibsa, T.R. andChunde, H.C. (2014): Characterization of Newcastle Disease Virus and poultry-handling practices in live poultry markets, Ethiopia. SpringerPlus3(1):1.

Natnael, T. (2015): Pathological AndSeroprevalence Studies On Infectious Bursal Disease In Chickens In And Around Bahir Dar, North West, Ethiopia. M.Sc. Thesis, Addis Ababa University, College of Veterinary Medicine and Agriculture, Department of Pathologyand Parasitology, Bishoftu, Ethiopia.

Nebiyu, Y., Berhan, T. and Kelay, B. (2013): Characterization of village chicken production performance under scavenging system in Halaba district of southern Ethiopia.Ethiop.Vet.J.,17(1): 69-80.

Nigussie, D., Alemu, Y., Tadelle, D., and Samuel, W. (2003): Onstation and on-farm evaluation of the 'hay-box chick brooder' using different insulation materials at debrezeitagricultural research center and denbi village, adaaworeda. In: proceedings of the $10^{\text {th }}$ annual conference of the ethiopian society of animal production (esap), august 21-23, held in addisababa, ethiopia. Pp. 211-216.

Nigussie, D., Van der waaij, L., Dessie, T. and Van Arendonk, J. (2010): Production objectives and trait preferences of village poultry producers of ethiopia: implications for designing breeding schemes utilizing indigenous chicken genetic resources. Trop. Anim. Health prod., 42: 519-529.

Serkalem, T., Hagos, A. and Zeleke, A. (2005): Sero-prevalence study of Newcastle disease in local chickens in central Ethiopia .Intern. J. Appl. Res Vet Med.,3: 1.

Smith, A .J. (1990): Poultry-Tropical Agriculturist series. CTA, Macmillan Publishers, London. Pp. 184-185.

Solomon, D. (2003): Growth performance and survival of local and white leghorn chickens under scavenging and intensive systems of management in Ethiopia. Livestock research for ruraldevelopment (15)11.

Solomon, D. (2004): Egg production performance of local and white leghorn hens under intensive and rural household conditionsinEthiopia.Jimma College of agriculturep.obox.307, Jimma, Ethiopia.

Solomon, D. (2007): Suitability of hay-box brooding technology to rural household poultry production system. Livestock research for rural development 19: (1).

Solomon, Z., Binyam, K., Bilatu, A. and Ferede, A. (2013): Village chicken production systems in Metekel zone, Northwest Ethiopia .Wudpecker J. Agri. Res., 2(9): 256- 262.

Tadelle, D. (2003): Phenotypic and genetic characterization of chicken ecotypes in Ethiopia. Ph.D. Thesis, Humboldt University, Germany.

Tadelle, D. and Ogle, B. (1996): Studies on scavenging poultry production systems in central highlands of Ethiopia. M.S.cThesis, presented Swedish University of Agricultural Sciences, Sweden.

Tadelle, D. (1996):Studies on village poultry production in the Central Highlands of Ethiopia.M.Sc. Thesis, Swedish University of Agricultural Science, Uppsala, Sweden

Tadelle, D. and Ogle, B. (2001): Village poultry production system in the central high lands of Ethiopia. Trop. Anim. Health prod., 33: 521-537.

Tadelle, D., Million, T., Alemu, Y. and Peters, K. (2003): Village chicken production systems in Ethiopia: use patterns and performance valuation and chicken products and socio economicfunctions of chicken. Livestock research for rural development (15):1.

Tadelle, D., Million, T., Alemu, Y. and Peters, K.J. (2003a): Village chicken production systems in Ethiopia: 1. Flock characteristics and performance; Livestock Research for Rural Development (15) 1. 
Major Constraints and Health Management of Village Poultry Production in Ethiopia: Review School of Veterinary Medicine, Jimma University, Jimma, Ethiopia

Terefe, D., Redeat, B., Hassen, C., Melaku, S., Abebe, M., Getachew, G., Kumela, L. And Delesa, D. (2015):Serological and molecular study of newcastle disease virus in village chickens in selected RiftValleyAreas, Ethiopia. J. Vet. Sci Technol. 6:264.

Tolossa, Y.H., Shafi, Z.D. and Basu, A.K. (2009): Ectoparasites and gastrointestinal helminthsof chickens of three agro-climatic zones in Oromia region, Ethiopia. Anim. Biol., 59: 289-297.

Udo, H., Asgedom, A. and Viets, T. (2001): Modeling the impact of intervention in village poultry productions. Livestock Community and Environment. Proceeding of the $10^{\text {th }}$ Conference of the Association of Institution for Tropical Veterinary Medicine Copenhagen, Denmark. Mekele University College, Ethiopia.

Wambura, P.N., Kapaga,A.M.andHyera, JMK (2000): Experimental trials with a thermostable Newcastle disease virus (strain I2) in commercial and village chickens in Tanzania. Preventive Veterinary Medicine. 2000; 43(2):75-83.

Weyuma, H., Singh, H. and Megersa, M. (2015):Studies on Management Practices Constraints of Back Yard Chicken Production in Selected Rural Areas of Bishoftu. J.Vet. Sci.Technol. S12: S12-003. doi:10.4172/2157-7579.1000S12-003

Zeleke, A., Sori, T., Gelaye,E.AndAyelet, G. (2005): Newcastle disease in village chickens in the southern and rift valley districts in Ethiopia. Int. J. Poult. Sci.7:507-510.

Citation: Ahmed. m, “ Major Constraints and Health Management of Village Poultry Production in Ethiopia: Review School of Veterinary Medicine, Jimma University, Jimma, Ethiopia ", International Journal of Research studies in Microbiology and Biotechnology, vol. 4, no. 1, p. 1-10, 2018. http://dx.doi.org/10.20431/24549428.0401001

Copyright: (c) 2018 Authors. This is an open-access article distributed under the terms of the Creative Commons Attribution License, which permits unrestricted use, distribution, and reproduction in any medium, provided the original author and source are credited. 